\title{
Vulnerable Populations in Prosocial Crowdfunding: Does the Framing Matter for Female and Rural Entrepreneurs?
}

\author{
Maria Figueroa-Armijos \\ EDHEC Business School \\ maria.figueroaarmijos@edhec.edu
}

\author{
John P. Berns \\ University of Mississippi \\ jberns@bus.olemiss.edu
}

\begin{abstract}
Prosocial crowdfunding was originally conceived as a financial mechanism to assist vulnerable unbanked populations, typically excluded from formal financial markets. It subsequently grew into a billiondollar scheme in a multi-billion-dollar crowdfunding industry. However, recent evidence claims prosocial crowdfunding may be shifting away from its goal to support the poor and underserved. Drawing on a composite social responsibility and framing theory framework, we examine the role that vulnerability plays in successfully raising funds in a prosocial crowdfunding context. We conduct multilevel logistic regressions on a sample of microloans allocated to 105,727 ventures in 64 countries. Our results indicate that applying for funds through a field partner which caters to vulnerable populations may in fact have a negative effect on the entrepreneur's request to be fully funded. Notwithstanding, framing the entrepreneur as being female or rural as key characteristics of individual vulnerability increases the project's likelihood to be fully funded.
\end{abstract}

\section{Introduction}

Crowdfunding is alternative financing, born with the advent of the internet, that democratized entrepreneurial financing [104]. It refers to fundraising that occurs online and is open to the general public (i.e., the crowd) who individually contribute money towards specific entrepreneurial endeavors or causes ([92]; [102]). A plethora of crowdfunding platforms exist to date, which can be broadly classified into four types of schemes: donation-based, lending-based, equity-based, and rewards-based [4]. In this spectrum, prosocial crowdfunding lies in between donationbased and lending-based crowdfunding (see figure 1 in [17]). Indeed, prosocial crowdfunding is a lendingbased scheme which provides funding in the form of debt without interest, and which emphasizes a prosocial agenda [17], making it distinct from other types of crowdfunding structures. Despite its significance, research on lending-based prosocial crowdfunding remains scant ([5]; [17]; [23]; [40]).

The purposeful individual selection of entrepreneurial projects and investment goals in crowdfunding [73] set the growing expectation that this alternative financial tool could offer the early stages of a more ethical entrepreneurial financing dynamic ([35]; [46]; [73]). However, evidence suggests that crowdfunding institutions may be increasingly seeking clients who are easiest to access, such as those living in urban rather than rural areas ([116]; [120]); those involved in businesses with rapid turnover such as retail, instead of agriculture ([37]; [65]); and the "better-off" of the poor ([26]; [44]). This evidence lies in contrast to the original goal of crowdfunding to support the unbanked and marginalized ([37]; [131]), shifting the industry away from the pursuit of poverty alleviation goals to give preference to financial sustainability and profitability [45]. Such a dynamic threatens the ethical underpinnings that demarcated the cumulative success of prosocial crowdfunding platforms as a novel mechanism to serve the most vulnerable.

Within the last several years, crowdfunding quickly became a critical financing option for entrepreneurs, with its full effects yet to be realized [11]. In its origins, crowdfunding platforms funneled over $\$ 5$ billion dollars to borrowers around the world in 2013 [127] and $\$ 16.2$ billion dollars in 2014 [98]. By 2015, the amount transferred to ventures across 400 platforms worldwide had more than doubled in a single year, reaching $\$ 34$ billion dollars ([68]; [98]). Five years later, in 2020, this figure was expected to grow to $\$ 200$ billion dollars, creating $\$ 3.2$ trillion in yearly economic value and 2 million new jobs [31]. By 2025, crowdfunding transactions are expected to surpass $\$ 300$ billion [125], an almost tenfold increase in only a decade. With its increased popularity, scholars and practitioners alike are focusing on exploring the ethical fabric of crowdfunding dynamics and if they deliver the societal benefits promised.

A plethora of crowdfunding platforms exist in the market, each with their own focus and utility scheme. Kiva, the leading prosocial crowdfunding platform, claims its mission is to connect people through lending 
to alleviate poverty [85]. Kiva's mission is echoed in its call for lenders where the catchphrase "Lend, get repaid, repeat" is used to encourage continuous support for the most vulnerable [85]. Recent evidence suggests that claiming a prosocial orientation that upholds societal values such as fairness and inclusiveness is likely to secure positive outcomes [35]. Nonetheless, only a few studies have focused on the ethical implications of mixing prosocial with traditional lending criteria in prosocial crowdfunding ([5]; [17]; [40]), with none yet exploring the role of vulnerability as a critical driver of funding success.

This study bridges two important theoretical frameworks, individual social responsibility and framing theory, to examine the role that vulnerability - and being female and rural as further individual proxies for it - play in successfully raising funds in a prosocial crowdfunding context. Indeed, given the still scarce and inconclusive evidence on the prosocial function of crowdfunding [35], this study answers the call for advancing theory in crowdfunding research [99] by examining the ethical implications within the fabric of this billion-dollar financing model.

Specifically, our study offers three main contributions to the business ethics literature regarding the dynamics of lending-based prosocial crowdfunding. First, this is the first study to integrate individual social responsibility and framing theory to explore the ethical underpinnings of prosocial crowdfunding. Thus, combining these two frameworks offers a novel integrative approach to add to the limited literature on ethics in crowdfunding. Second, we advance research on the dynamics of prosocial crowdfunding by exploring the role of vulnerability markers on entrepreneurs' profiles. Specifically, we examine the impact of partnering with field partners who cater to vulnerable populations and unexplored individual characteristics that delineate the greatest vulnerability - being female or rural. In doing so, we provide evidence to inform if indeed the crowdfunding industry, in the context of prosocial crowdfunding, is abandoning its mission to serve the poor [38], which has important implications for the business ethics literature [8]. Third, different from prior studies (e.g. [5] who studied funded ventures only) we examine prosocial response on the universe of entrepreneurs on Kiva, which offers a more complete analysis of the nature of prosocial individual responsibility in crowdfunding success.

Our research findings indicate that demarcating vulnerability at the individual level is critical for successful funding. Indeed, we find that framing vulnerability at the individual level for female entrepreneurs actually lessens the negative impact from the field partner. These findings suggest that institutions at the front lines of poverty alleviation may be hindering successful funding, yet individually, the vulnerable populations are still managing to receive the assistance they request. This conflict offers noteworthy theoretical and practical ethical implications in prosocial crowdfunding, suggesting that framing the crowdfunder's attention on vulnerability attributes at the individual level may serve to obscure [22] other contextual factors on the entrepreneur's profile.

\section{Theoretical Framework}

\subsection{Prosocial Crowdfunding and Vulnerable Populations}

With the advent of technology, crowdfunding opened up the prospect of democratized entrepreneurial finance [104], breeding a new internetbased venue for the facilitation of microloans. However, whereas crowdfunding emerged in the $21^{\text {st }}$ century, its contemporary dynamic evolved from the foundations laid down by the broader sphere of microfinance. Historically, microfinance grew from the modest premise of offering start-up loans without a collateral as a poverty alleviation remedy for the most vulnerable in the developing world ([79]; [94]), typically excluded from formal financial markets ([37]; [131]). Notwithstanding, the distinctive and increasingly divergent premise that sets crowdfunding apart from microfinance is the institutional roots and complex settings that constrain the latter in the particular contexts where its agents operate [20].

Indeed, whereas crowdfunding levels the playing field in the absence of intermediaries, and thrives amidst the absent or meager regulations to control individual online endeavors in mostly developed economies, non-governmental and non-profit microfinance organizations are subject to geographyspecific institutional contexts [20], which involve banking regulations and regular audits ([80]; [81]). The intricate local system of borrowers, local social networks, community loan agents, network operators, and other financing organizations that microfinance organizations depend upon for their daily operations place "significant institutional constraints" (p. 11) that gave way to the emergence of a new heterogeneous financial innovation, where less stringent online platforms succeed (see [20] for a full review) with new easy-to-access alternative financial instruments [19].

Amidst extant guidelines or regulation, online crowdfunding platforms emerged as popular hubs that enable early-stage entrepreneurs to connect with prospective crowdfunders, who contribute an amount of money towards an entrepreneurial venture [97]. Indeed, sizable evidence suggests entrepreneurs are 
increasingly using crowdfunding as a steppingstone to transform an idea into a product and test the market potential of a new venture ([27]; [102]). The distinctive means that now connect entrepreneurs and crowdfunders lead the latter to practice a mix of traditional and prosocial lending criteria ([5]; [17]), further transforming crowdfunding into a "prosocial" lending field [55] where individual ethical principles towards society [56] lead individuals to take action [online] towards a positive impact [75].

Indeed, the emergence of prosocial crowdfunding has allowed altruistic individuals from across the globe to directly assist the unbanked population [94], bypassing the profit-oriented middlemen (e.g. banks, venture capitalists) who typically lack a social or ethical lens [41]. Interest-free lending-based crowdfunding laid the foundation for a novel financing dynamic, where crowdfunders can derive social or ethical utility beyond financial return ([17]; [40]). Through purposeful selection of entrepreneurial projects [73], crowdfunders' decisions on prosocial platforms take a meaningful and influential role [8], setting the expectation that crowdfunding could offer a means to more ethical entrepreneurial finance [35].

Peer-to-Peer (P2P) lending or 'crowdlending', as it was initially called, swiftly became the most valuable type of crowdfunding [133], serving as the primary funding mechanism for the supply of credit and payment services to the world's poor [25]. In its early beginnings, poverty alleviation practitioners hoped that borrowers would establish enterprises that would enable them to break the cycles of poverty [131]. Early reports suggested that crowdfunding and the process of micro-lending directly supported entrepreneurial development ([7]; [13]), while significantly impacting poverty reduction and female empowerment ([21]; [78]). A decade later, mounting evidence suggests that crowdfunding does improve the financing prospects of businesses that claim a prosocial orientation [35].

Prosocial orientation refers to a project that exhibits a stronghold for values such as fairness, inclusiveness, and awareness and care towards others ([107]; [35]; [117]). It is assumed that projects that display a societal benefit are more likely to receive support from investors on digital platforms [35]. However, evidence on the prosocial function of crowdfunding remains scarce and inconclusive ([17]; [35]). Furthermore, the dynamics of prosocial crowdfunding within the microfinance and business ethics literatures are only recently awakening scholarly discussion at the intersection of both fields ([17]; [40]). Only a few studies investigate the intricate financial and ethical motives that are concurrently reflected in crowdfunders' behavior on prosocial platforms (see [5]; [17]; [40]), leaving a void in our understanding of the ethical implications of funding a venture that claims a prosocial orientation [35].

\subsection{Individual Social Responsibility and Prosocial Behavior in Crowdfunding}

The concept of social responsibility has permeated the boundaries of entrepreneurial finance including crowdfunding, social finance, and socially responsible investing [62]. Historically, the concept of social responsibility has been associated with corporate actions rather than the actions of individuals [117]. However, a business is an artificial person and therefore cannot claim direct responsibilities [53]; the responsibility lies with the people who direct its actions. The individual is therefore at the core of social responsibility [117] and it is the individual's "obligation to consider the effects of their decisions and actions on the whole social system" ([33], p. 167).

Embedded in the original ponderings of social responsibility is the conception that individuals "should help others in need" ([108], p. 34), a prosocial behavioral tendency that can most likely be traced to our early childhood [117] and which continues through adulthood ([47]; [52]). Social responsibility is thus expressed through an individual's prosocial attitudes and acts as a reflection of their ethical values [117]. Social responsibility theory posits that individuals face two distinct motives in the process of micro-lending; an idealistic/altruistic motive pulls the investor towards ventures which support a social cause, whereas a strategic motive pulls the investor towards financially sound investments that signal a positive return [64]. While prior research suggests that a mix of these criteria may be found in crowdfunding lending decisions ([5]; [17]; [40]), social responsibility theory suggests that prosocial crowdfunders are motivated by non-financial factors (see [5]; [17]).

Many micro-lending non-profit organizations in the developing world focus on social outreach and social impact [40], seeking primarily to assist the most vulnerable ([54]; [121]), reduce poverty ([114]; [78]; [70]), empower women ([29]; [122]), and address basic health and children's needs [90]. Similarly, micro-lending crowdfunders seek to make a social impact by supporting the most vulnerable [40], a dynamic often explored in microfinance ([54]; [121]; [123]), but rarely investigated in prosocial crowdfunding studies which use a business ethics lens.

In a study of entrepreneur narratives on socially motivated platforms such as Kiva, the opportunity to assist others is a determining factor in providing funding, superseding the business potential and financial return [5]. In another study, [110] use data from the crowdfunding platform Kickstarter and find that social entrepreneurs (as opposed to commercial 
entrepreneurs) rely extensively on explicit linguistic cues to appeal to investors. A more recent study [35] concludes that entrepreneurial projects emphasizing a prosocial motive on prosocial platforms like Kiva are more likely to succeed. Furthermore, pictures that frame a perception of neediness or vulnerability are also positively linked to loan funding speed [71]. While these studies offer compelling evidence that individual narratives aid in securing funding by prosocial lenders, it is not known if the narratives of the institutions themselves used by vulnerable entrepreneurs offer a similar benefit. Thus, following a similar line of thought, we propose that entrepreneurs using field partner institutions (e.g. microfinance institutions) specifically tailored to serve vulnerable populations will be better positioned to garner attention from prosocial crowdfunders.

Hypothesis 1. There will be a positive relationship between the entrepreneur's field partner servicing the vulnerable and the loan being fully funded in a prosocial crowdfunding platform.

\subsection{Framing Theory and Prosocial Behavior in Crowdfunding}

The crowdfunding business model unfortunately suffers from information asymmetry between entrepreneurs and crowdfunders [16]. In this setting, explicit cues [110] or phrases [35] in the narrative [5] or through pictures [71] can narrow this gap to portray need more accurately. Furthermore, digital environments, such as those where prosocial crowdfunding platforms operate, display information in a "hierarchical (hypertext) structure" which walks the crowdfunder through a path of information [100]. The structure of the hierarchical flow of information displayed to crowdfunders is critical to establish emphasis ([87]; [132]) on the specific prosocial cues that can determine the success of a project [35].

The framing literature ([51]; [57]; [60]; [113]), an increasingly attractive theoretical construct in the management literature, offers an apt framework to understand this phenomenon. The concept of framing first appeared in a seminal work on frame analysis, which posited that the context, selection and organization of information affects how an audience interprets and reacts to such messages [60]. In the context of prosocial crowdfunding, framing serves to induce specific information about a project [28] which sets the expectations among crowdfunders. Prosocial framing can be identified anywhere in the description of the project - titles, blurbs, phrases [35], and even pictures [71]. How prosocial cues are organized and framed in the entrepreneur's profile delineates salient information, thus influencing individuals to act towards a characteristic or funding goal, typically with positive outcomes ([12]; [35]; [96]; [105]).

Effective prosocial framing has important business ethics implications as it sets the conditions for project success [35]. Distinctive markers on the entrepreneur's online profile can set it apart from other similar projects [57], and direct the audience towards specifically framed attributes [35], such as vulnerability markers including whether the entrepreneur is female or rural. The extent of the emphasis or number of cues required on a specific frame to ensure a project's success is still unknown [35]. However, a small number of references can be effective to highlight a feature that distinguishes the project from a large pool of candidates [66]. Initial evidence suggests that characteristics from a photo ([42]; [71]; [111]) or soft facts highlighted in the narrative ([67]; [39]) on the profile can be effective.

\subsection{Framing Female in Prosocial Crowdfunding}

In the dynamics of prosocial crowdfunding, an increasing number of studies suggest that the most critical drivers for a project's success lies with the founder ([30]; [58]). Despite this important revelation, evidence on the role of being a female entrepreneur in this context remains scant and mixed. For instance, a recent study on gender dynamics on Kickstarter finds that women seek and raise significantly lower levels of capital than men [97]. On the contrary, another study also using Kickstarter data finds that women are more successful when they do seek venture capital [112]. Although important scholarly contributions are still to be made to explain the intricacies of being a female entrepreneur in online crowdfunding [99], especially in a prosocial context, preliminary evidence suggests that crowdfunding is increasingly lessening the gender bias ([3]; [61]).

As of September 2020, 81 percent of borrowers on Kiva are female [85], and evidence shows their loans are funded at a rate 40 percent faster than male borrowers [63]. This rate for a prosocial crowdfunding platform is not surprising - women's entrepreneurship is widely documented as a critical tool to alleviate poverty in the developing world [101] and women's empowerment is at the core of a multitude of international organizations and microfinance institutions ([29]; [76]; [77]; [122]). Accordingly, female entrepreneurs framing their project's funding as a life-changing source of empowerment [29], setting language cues [110], and a profile photo ([42]; [71]; [111]) that promote a specific prosocial objective may seem to be bound to influence individual social responsibility and lead to funding success. 
Indeed, recent evidence from the largest prosocial platform, Kiva, reveals that field partners who are noted for higher social performance because they focus on lending to women are more likely to see their loans refinanced [40] which is consistent with prior work which suggests crowdfunders increasingly value a prosocial orientation [115]. However, it is important to note that crowdfunders in this study seemed keen to empower women "but not others beyond the borrowers themselves" and that they "appear to care about the borrowers' vulnerability, but to a varying extent" ([40], p. 2). These findings complement prior work [17], which finds that despite a prosocial setting, crowdfunders on prosocial platforms balance a dynamic where both financial and social cues play a critical role. Indeed, in another study on Kickstarter, prosocial framing is positively related to project success "yet only when it is moderately emphasized." ([35], p. 1). Thus, we propose that the presence of key characteristics in the entrepreneur's profile which may indicate increased need or vulnerability, such as being female, will positively moderate the relationship between the field partner's social orientation and the entrepreneur's loan being fully funded.

Hypothesis 2. Being a female entrepreneur will positively moderate the relationship between a crowdfunding institution's social orientation and the entrepreneur's loan being fully funded in a prosocial crowdfunding platform.

\subsection{Framing Rural in Prosocial Crowdfunding}

According to a report [124] poverty is mostly concentrated in rural areas. The reasons for this are many. Along with limited funding accessibility ([36]; [49]), there are persistent perceptions of low returns, lack of knowledge, and lack of business practices amongst rural entrepreneurs which limits their ability to secure resources [1]. Further limiting rural entrepreneurs are the small customer bases [49], the constrained proximity to networks and infrastructure [32], and the perception of the environment being less welcoming [59] and "weak" in its retention of highvalue human capital [93]. When combined, these factors hamper the aspirations of existing business owners and early-stage entrepreneurs in rural areas.

These obstacles not only constrain populations in rural areas, but also constrain financial institutions from servicing them, making reaching these rural populations a defining prosocial goal in crowdfunding. Some initiatives have directly targeted marginalized rural areas, including global alliances that mobilize millions of dollars to support the needs of the most excluded and vulnerable typically found in rural settings [129]. However, reaching remote populations is difficult and poses a myriad of challenges [95].

A major accolade of many crowdfunding sites is the ability to overcome the obstacle of distance. Markers on the entrepreneur's profile which delineate a rural setting as a defining characteristic, via a suggestive narrative ([39]; [67]) or picture ([42]; [71]; [111]), can serve to frame emphasis [35]. Therefore, we propose that entrepreneurs in rural areas working with a field partner who caters to vulnerable populations will be at a greater advantage when seeking funding for their entrepreneurial endeavors.

Hypothesis 3. Being a rural entrepreneur will positively moderate the relationship between a crowdfunding institution's social orientation and the entrepreneur's loan being fully funded in a prosocial crowdfunding platform.

\section{Method}

\subsection{Sample and Method}

This study uses data collected directly from the socially motivated crowdfunding platform Kiva.org. Kiva is a non-profit organization that was founded in 2005 with a global mission to "connect people through lending to alleviate poverty" [85]. Borrowing entrepreneurs and crowdfunders from all over the world can sign up through Kiva's online platform to either borrow or lend funds. Each entrepreneur goes through a financial intermediary, a field partner, who works with Kiva to secure financing. Each entrepreneur's loan, through the field partner, can then be backed by crowdfunders who, from any corner of the world, voluntarily sign up with Kiva to lend funds to whomever they want. Prior microlending research in marketing [55] and entrepreneurship ([6]; [5]; [17]; [40]) also uses data from Kiva when examining phenomena within prosocial crowdfunding.

The sample used in this study includes public data available on Kiva's website from 2008 up until early 2013. A scraper program was created to collect this data, which includes data on borrowing entrepreneurs, crowdfunders, field partners, and countries. After dropping projects with incomplete information, our final sample is a cross-sectional dataset consisting of 105,727 projects, which we use to test our hypotheses. Since our dependent variable (fully funded) is a $1 / 0$ dichotomous variable, a discrete binary response model is most appropriate. Logit and probit modeling are the most common approaches for analyzing such data [69]. We choose logit for our regression analyses because this type of modeling offers more precise results when analyzing a skewed dependent variable 
as we are [72]. Logistic regression analysis is commonly used in similar previous crowdfunding research (e.g. [9]; [35]). Furthermore, since projects are nested within countries, and country effects impact investment [91], we use multilevel logistic regression with standard errors clustered by country. This approach allows us to account for spatial autocorrelation between participants from the same country [48] and avoid overparameterization. This method follows previous crowdfunding research dealing with similar sample data (e.g. [10]; [130]).

\subsection{Dependent Variable}

The dependent variable of interest in this study is whether the entrepreneur's requested loan is fully funded. Fully funded is designed as a dichotomous variable with 1 indicating the loan was fully funded by the crowd and 0 otherwise. Thus, we model the logodds in the probability of a project being fully funded. Parameters from this logit scale estimation indicate the direction of the effect of each explanatory variable on the probability of a project being fully funded. In order to interpret the magnitude of these effects, we also calculate and present on Table 4 the first differences or marginal effects of the predicted values (see [50] for a similar approach). The marginal effects indicate the change in the probability of a project being fully funded given some change in the explanatory variable of interest, while holding other independent and control variables at their means ([82]; [83]; [128]).

\subsection{Independent Variable}

Kiva field partners earn badges ${ }^{1}$ for servicing a population segment or prosocial goal. Each field partner displays social performance badges on the entrepreneurs' profiles whom they support on Kiva, which directly indicate their scope of action [86] (see figure 1 for an example). In our study, we focus on the two social performance badges which most precisely resemble the social mission of Kiva: antipoverty and vulnerable groups. Indeed, prior research indicates that in a micro-lending setting, individuals seek to maximize social impact by primarily supporting the most vulnerable ([40]; [54]; [121]) or through initiatives that aim to reduce poverty ([114]; [78]; [70]). Thus, the variable vulnerable in our study equals 1 if the institution managing the loan has an 'antipoverty' or 'vulnerable groups' badge on the entrepreneur's profile, and 0 otherwise.

\footnotetext{
${ }^{1}$ Categories of badges include: antipoverty focus, vulnerable group focus, family and community empowerment, client voice, innovation, entrepreneurial support, facilitation of savings.
}

\subsection{Moderating Variables}

To examine the factors that moderate the effects of an entrepreneur's project being fully funded in a prosocial crowdfunding context, we examine two moderators for vulnerability - female and rural. Female is measured as a dummy variable where 1 indicates the entrepreneur is female and 0 otherwise. Entrepreneurs whose funding requests had both or neither male and female wording had their name run through GenderAPI software. Rural is measured as a dummy where 1 indicates the entrepreneur's project's main operation is located in a rural area and 0 otherwise. We use agriculture as a proxy for rural. This proxy is appropriate as being an individual in poverty, working in agriculture, and in a rural location are often linked to one another [89] in the developing world. According to [129] and [124] the most vulnerable populations and poverty are found in rural settings, where agriculture is the predominant activity.

\subsection{Control Variables}

We control for several types of variables to account for alternative explanations. These control variables include loan and field partner characteristics. We use these controls to account for other information available to the crowdfunder from the borrowing entrepreneur's profile on the prosocial crowdfunding platform. This is appropriate as the information on these publicly available profiles form the bases for the crowdfunders' funding decisions ([10]; [102]).

First, following prior research in crowdfunding, we control for loan characteristics which may impact the funding decision. We control for the amount requested (in hundreds of US dollars), as prior research indicates funding decisions may vary according to the size of the loan requested ([6]; [10]). We also control for both the repayment term (in months) and whether the repayments were to take place at regular intervals, or if they were irregularly scheduled repayments ([10]; [55]). The repayment schedule is coded as a binary variable with 1 representing an irregular repayment schedule and 0 indicating a regular repayment schedule. As Kiva policies state, lending through Kiva "involves risk of principal loss. Kiva does not guarantee repayment or offer a return on your loan" [85]. Finally, we control for the year of the loan request with dichotomous variables representing each year in the sample to account for variations over time ([43]; [130]). 
We also control for various field partner characteristics since the field partners intermediating these loans are tasked with selecting and monitoring loans ([15]; [118]), offering the crowd further information from which to make funding decisions. We control for field partner risk rating which is rated by Kiva on a $0-10$ scale ([5]; [55]). We also control for the field partner delinquency rate which is the percentage of delinquent loans in which the field partner is involved [71]. Furthermore, we control for the number of field partner entrepreneurs (in thousands) and field partner dollars (in millions) [17]. These are measured as a count of the number of entrepreneurs previously funded by the field partner and the total number of US dollars the field partner has dispersed on Kiva. Finally, we control for the average field partner loan (in hundreds of US dollars) and the average field partner loan term (in months), measured as the average number of months to repay the loan to the field partner, so it could be reimbursed to crowdfunders [18]. A prior study [6] follows a similar logic regarding field partner characteristics in crowdfunding.

\section{Results}

Table 1 presents the results from our multilevel logistic regression analyses on the dependent variable fully funded. This analysis includes testing of a baseline model (Model 1), followed by models incorporating our three variables individually and then all together (Models 2-5), followed by incorporating our two interactions individually (Models 6 and 7), and finally presenting our full model (Model 8). Hypothesis 1 predicts a positive relationship between the entrepreneur's field partner servicing those who are vulnerable and the loan being fully funded in a prosocial crowdfunding platform. As seen in Model 2, the coefficient for antipoverty or vulnerable group is significant in a negative direction $(\beta=-0.59, p<0.05)$. Surprisingly, this result suggests that entrepreneurs serviced by field partners focusing on vulnerable groups have lower odds for their project to be fully funded. This result holds throughout the various model specifications, including the full model, Model 8 ( $\beta=$ $-0.60, p<0.05)$. Therefore, we find counter evidence for hypothesis 1 , which is not supported.

Hypothesis 2 predicts that being a female entrepreneur will positively moderate the relationship between a crowdfunding institution's catering vulnerable populations and the entrepreneur's loan being fully funded in a prosocial crowdfunding platform. Female is positively related to full funding as seen in Model 3 ( $\beta=1.22, p<0.01)$ and this finding holds in all other model specifications, including the full model, Model $8(\beta=1.01, p<0.01)$. We next incorporate the interaction and, as seen in Model 6, the coefficient for vulnerable $x$ female is positive and significant $(\beta=0.41, p<0.05)$. This result is consistent in the full model, Model $8(\beta=0.39, p<0.05)$, suggesting that framing being a female entrepreneur as an individual marker of vulnerability positively moderates the odds of the project getting full funding. Therefore, hypothesis 2 is supported.

Hypothesis 3 predicts that being rural will positively moderate the relationship between a crowdfunding institution's catering vulnerable populations and the loan being fully funded. Rural is positively related to full funding as seen in Model 4 ( $\beta$ $=0.66, p<0.01)$ and this finding holds in all other model specifications, including the full model, Model $8(\beta=0.96, p<0.01)$. We next incorporate the interaction and, as seen in Model 7, the coefficient for vulnerable $x$ rural is negative and not significant. This result holds in the full model, Model 8. Therefore, hypothesis 3 is not supported.

Table 1. Multilevel logistic regression results

\begin{tabular}{|c|c|c|c|c|c|c|c|c|}
\hline \multirow{3}{*}{$\begin{array}{l}\text { Tariable Model } \\
\text { Vulherable }\end{array}$} & & $(4)$ & & & & & & $(8)$ \\
\hline & & $-0.59 \%$ & & & $-0.46^{* *}$ & $-0.62 * *$ & $-0.42^{* *}$ & $-0.60 \%$ \\
\hline & & (0.24) & & & $(0.22)$ & $(0.26)$ & $(0.20)$ & (0.24) \\
\hline \multirow[t]{2}{*}{ Female } & & & $1.22 \cdots$ & & $1.30 \cdots$ & $1.00 \cdots$ & $130 \cdots$ & $1.01 \cdots$ \\
\hline & & & $(0.22)$ & & (0.21) & $(0.17)$ & (0.21) & (0.16) \\
\hline \multirow[t]{2}{*}{ Vulnerable x Female } & & & & & & $0.41 *$ & & $0.399^{* *}$ \\
\hline & & & & & & $(0.20)$ & & $(0.20)$ \\
\hline \multirow[t]{2}{*}{ Rural } & & & & $0.06 \cdots$ & $0.86 \cdots$ & $0.866^{* *}$ & $1.04 \cdots$ & $0.96 \cdots$ \\
\hline & & & & (0.16) & (0.16) & (0.16) & $(0.24)$ & (0.23) \\
\hline \multirow[t]{2}{*}{ Vulherbble x Rural } & & & & & & & -0.22 & -0.13 \\
\hline & & & & & & & (0.29) & $(0.28)$ \\
\hline \multirow[t]{2}{*}{ Amount requested (hundreds) } & $-0.06 \cdots$ & $-0.06 \cdots$ & $-0.07 \cdots$ & $-0.06 \cdots$ & $0.07 \cdots$ & $-0.07 \cdots$ & $-0.07 \cdots$ & $-0.07 \cdots$ \\
\hline & (0.01) & $(0.01)$ & $(0.01)$ & $(0.01)$ & $(0.01)$ & $(0.01)$ & $(0.01)$ & $(0.01)$ \\
\hline \multirow{2}{*}{ Reppyment temm (montas) } & $-0.06 \cdots$ & $-0.07 \cdots$ & $-0.06 \cdots$ & $-0.06 \cdots$ & $-0.06 \cdots$ & $-0.06 \cdots$ & $-0.06 \cdots$ & $-0.06 \cdots$ \\
\hline & $(0.02)$ & $(0.02)$ & $(0.02)$ & $(0.02)$ & $(0.02)$ & (0.02) & $(0.02)$ & $(0.02)$ \\
\hline \multirow[t]{2}{*}{ Irregulury ycheduled repeyments } & 0.30 & 0.38 & 0.50 & 0.09 & 0.28 & 0.29 & 0.29 & 0.29 \\
\hline & $(0.30)$ & $(0.31)$ & (0.34) & (0229) & (0.31) & $(0.31)$ & (0.32) & (0.32) \\
\hline \multirow[t]{2}{*}{ Field parterer risk rating } & $0.45 \cdots$ & $0.46^{* * *}$ & $0.49 \cdots$ & $0.42 \cdots$ & $0.46 \cdots$ & $0.47 \cdots$ & $0.46 \cdots$ & $0.46 \cdots$ \\
\hline & $(0.08)$ & $(0.07)$ & $(0.08)$ & $(0.08)$ & $(0.08)$ & $(0.08)$ & $(0.08)$ & $(0.08)$ \\
\hline \multirow[t]{2}{*}{ Field partaer delinquency rate } & .0 .52 & .0 .59 & .0 .16 & -0.65 & .0 .54 & -0.49 & -0.51 & -0.48 \\
\hline & (0.81) & (0.74) & (0.71) & (0.86) & $(0.73)$ & $(0.73)$ & (0.73) & (0.74) \\
\hline \multirow[t]{2}{*}{ Field partner entrepreneurs (hoosands) } & -0.04 & -0.06 & -0.04 & -0.03 & -0.04 & -0.04 & -0.04 & -0.04 \\
\hline & (0.04) & $(0.04)$ & $(0.04)$ & $(0.04)$ & (0.04) & $(0.04)$ & $(0.04)$ & $(0.04)$ \\
\hline \multirow[t]{2}{*}{ Field partuer dollars (millions) } & -0.15 & .0 .06 & -0.16 & -0.16 & .0 .11 & -0.12 & -0.11 & -0.12 \\
\hline & (0.11) & (0.13) & $(0.12)$ & (0.11) & (0.13) & (0.13) & (0.13) & (0.13) \\
\hline \multirow[t]{2}{*}{ Average feld perther low (kundreds) } & 0.08 & $0.11^{*}$ & $0.09 *$ & 0.03 & $0.10^{*}$ & $0.11^{\circ}$ & $0.10^{*}$ & $0.11^{*}$ \\
\hline & $(0.05)$ & $(0.06)$ & $(0.05)$ & (0.05) & (0.06) & $(0.00)$ & $(0.06)$ & $(0.06)$ \\
\hline \multirow{2}{*}{ Average field parther loon temm (months) } & $-0.23 *$ & $-0.27 \cdots$ & $-0.23 * *$ & $-0.23^{*}$ & $.026 \cdots$ & $-0.26^{\cdots *}$ & $-0.26^{* *}$ & $-0.26 \cdots$ \\
\hline & $(0.10)$ & $(0.10)$ & $(0.09)$ & $(0.10)$ & $(0.10)$ & $(0.10)$ & $(0.10)$ & $(0.10)$ \\
\hline \multirow[t]{2}{*}{ Intrercept } & $10.03 \cdots$ & $1120 \cdots$ & $9.73 \cdots$ & $10.66 \cdots$ & $1020 \cdots$ & $1031 \ldots$ & $10.17 \%$ & $10.29 \cdots$ \\
\hline & (0.81) & (0.94) & $(0.81)$ & $(0.86)$ & $(1.00)$ & $(0.98)$ & (1.00) & $(0.99)$ \\
\hline \multirow[t]{2}{*}{ Courty (variance compononat) (n=64) } & $1.78^{\circ \cdots *}$ & $2.24 \cdots$ & $1.85 \cdots$ & $170 \%$ & $2.10 \cdots$ & $2.18+\cdots$ & $2.11 \cdots$ & $2.18 \cdots$ \\
\hline & $(0.61)$ & (0.94) & $(0.67)$ & $(0.59)$ & $(0.80)$ & $(0.92)$ & (0.88) & (0.93) \\
\hline Year dummies includoded & Yes & & Yes & Yes & Yes & Yes & Yes & Yes \\
\hline 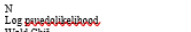 & $\begin{array}{l}105,727 \\
-5665.55 \\
0.05254 .\end{array}$ & $\begin{aligned} 105.727 \\
5.5630 .40\end{aligned}$ & 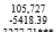 & 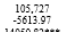 & $\begin{array}{l}105.727 \\
.5351 .69 \\
0.5306\end{array}$ & $\begin{aligned} 105.727 \\
-5377.03 \\
0.53 .3\end{aligned}$ & $\begin{array}{r}105.727 \\
-5351.12 \\
.7352 .\end{array}$ & $\begin{array}{l}105.727 \\
.534583 \\
0.5633\end{array}$ \\
\hline
\end{tabular}

\section{Discussion}

\subsection{Theoretical Contributions}

Our study explores prosocial crowdfunding as a novel financing mechanism to serve the most vulnerable, an issue seldom explored in the literature, but which derives significant business ethics implications with approximately 1.5 billion dollars dispersed to over 3.7 million borrowers around the globe (Kiva, 2020b). In this regard, our study makes 
several contributions to the literature. First, using a composite individual social responsibility and framing theoretical lens, our study responds to the call to advance theory in crowdfunding research [99] by shedding new light on the role of vulnerability as a critical driver of funding success in prosocial microlending. Whereas both theoretical perspectives have been previously applied, they have only begun to permeate scholarly work in crowdfunding in the last few years. Combining both perspectives allows us to investigate the intricate financial and ethical motives that are concurrently reflected in crowdfunders' behavior on prosocial platforms (see [5]; [17]; [40]), expanding our limited knowledge on the role of individual social responsibility (Hill et al., 2007) in lending-based prosocial crowdfunding.

Second, our study contributes to the literature on the intricate dynamics of crowdfunding [119] and business ethics in entrepreneurial financing [8]. Our results suggest that entrepreneurs who go through field partners that cater to vulnerable populations are in fact less likely to be fully funded. This runs contrary to our theoretical conjectures which propose that vulnerability markers would drive crowdfunders to act in a socially responsible way and 'do what is right' [56] to support those in need as an extension of their ethical values [117]. Notwithstanding, this result stands in alignment with the scant research on prosocial crowdfunding that takes on an ethics lens (e.g. [17]; [35]) which finds that while societal benefit is desirable, it is not necessarily sufficient to warrant funding as crowdfunders also seek viable projects. Our results thus confirm prior findings and further highlight that general indicators of vulnerability offered by field partners (i.e. intermediaries) may not be sufficient to frame need and secure full funding.

Finally, in line with our expectations, we find that female entrepreneurs are more likely to receive full funding and that this positively moderates the relationship between the field partner servicing vulnerable populations and the entrepreneur securing full funding. This result confirms that personal values of ethics and social responsibility interweave [74] when a key characteristic of the entrepreneur - being female - is framed as a life-changing source of female empowerment [29]. This result is consistent with prior research on prosocial crowdfunding which shows that prosocial framing is positively linked to project success "only when it is moderately emphasized" ([35], p. 1) because crowdfunders "appear to care about the borrowers' vulnerability" [...] "but not others beyond the borrowers themselves" ([40], p. 2). This finding is also consistent with an increasing number of studies which suggest that the most critical drivers of project success depend on the characteristics of the founder ([30]; [58]).

\subsection{Practical and Policy Implications}

Our study also offers two critical insights for practical application. First, only a few studies to date investigate the intricate financial and ethical motives reflected in crowdfunders' behavior on prosocial platforms (see [17]; [35]; [40]). The lack of studies in this area amounts to a void in our understanding of the ethical implications of financing dynamics on prosocial crowdfunding platforms [35]. Whereas early research in crowdfunding reflected an immediate positive effect of a prosocial orientation on project success [5] more recent research suggests that crowdfunders in a prosocial setting "tend to act strategically" rather than altruistically, following indicators of financial performance and risk avoidance ([17], p. 169). Our results suggest that a prosocial orientation, depicted by vulnerability badges from the field partner supporting the loan, is not conducive to full funding. Combined with prior research, our findings are noteworthy for the practitioner and policymaker seeking to use prosocial crowdfunding platforms as a mechanism to serve the most vulnerable. Albeit becoming a billionaire financing model, success in prosocial crowdfunding may require more than working through a field partner that supports vulnerable populations.

Second, whereas some evidence suggests that prosocial platforms have begun to stray from their intended purpose to serve the most disadvantaged (i.e. mission drift), our results indicate that individual vulnerability attributes highlighted on the entrepreneur's profile serve to attenuate other contextual factors. In particular, female entrepreneurs in our sample are able to secure the financing they seek despite teaming up with field partners who may actually act as a double-edged sword [17]. This vital finding suggests that the individual social responsibility of crowdfunders is reflected in their effective response to fund the most vulnerable entrepreneurs on a prosocial setting. This tactic can help the entrepreneur establish a prosocial feature that can distinguish the project from the large pool of candidates on the platform. Albeit the exact number of cues required for emphasis is still unknown [35], a defining profile photo ([42]; [71]; [111]) or soft facts emphasized ([67]; [39]) on the entrepreneur's profile narrative can lead potential crowdfunders to fulfill their prosocial individual responsibility to empower female entrepreneurs ([29]; [122]).

\section{Conclusion}

Our study contributes evidence that individual crowdfunders on a prosocial crowdfunding platform 
lend to vulnerable populations who are able to frame their vulnerability at the individual level -namely female entrepreneurs- whereas higher level field partner indicators may be in fact detrimental to secure full funding. We contribute to theory-building in ethical crowdfunding by bridging individual social responsibility and framing as a composite theoretical framework. Using this framework, our study offers evidence that prosocial crowdfunding does indeed support the vulnerable and poor through a unique framing mechanism. Our research highlights the importance of framing persuasive arguments at the individual level to achieve this goal. Together, these findings offer an additional outlook into the dynamics of lending-based prosocial crowdfunding, specifically of the vulnerability framing mechanisms at play for vulnerable populations and poverty alleviation. These small ventures, often created out of necessity by vulnerable groups, comprise the bulk of global entrepreneurial activity ([106]; [109]; [126]) and the study of the ethical dynamics behind is thus of paramount economic and social importance.

\section{References}

[1] Acs, Z.J., \& Kallas, K. (2008). State of literature on small-to-medium sized enterprises. In Yago G., Barth, J.R., \& Zeidman, B., (Eds.), Ent and Emerging Domestic Markets. NY: Springer.

[2] Aernoudt, R. (1999). Business angels: Should they fly on their own wings? Venture Capital, 1(2), 187-195.

[3] Agrawal, A., Catalini, C., \& Goldfarb, A. (2014). Some simple economics of crowdfunding. Innov Policy and Econ, 14(1), 63-97.

[4] Ahlers, G. K., Cumming, D., Gunther, C., \& Schweizer, D. (2015).

Signaling in equity crowdfunding. Entrepreneurship Theory and Practice, 39(4), 955-980.

[5] Allison, T.H., Davis, B.C., Short, J.C., \& Webb, J.W. (2015).

Crowdfunding prosocial. Ent Theory and Practice, 39(1), 53-73.

[6] Allison, T.H., McKenny, A.F., \& Short, J.C. (2013). The effect of ent rhetoric on microlending. J of Bus Vent, 28(6) 690-707.

[7] Anthony, D. (2005). Cooperation in microcredit borrowing groups. American Soc Review, 70(3), 496-515.

[8] André, K., Bureau, S., Gautier, A., \& Rubel, O. (2017). Beyond the opposition between altruism and self-interest. Journal of Business Ethics, 146(2), 313-332

[9] Anglin, A.H., Short, J.C., Drover, W., Stevenson, R.M., McKenny, A.F., \& Allison, T.H. (2018). The power of positivity? Journal of Business Venturing, 33(4), 470-492.

[10] Anglin, A.H., Short, J.C., Ketchen, D.J., Allison, T.H., \& McKenny, A.F. (2020). Third-party signals in crowdfunded. Ent Theory and Practice, 44(4), 623--644.

[11] Assenova, V., Best, J., Cagney, M., Ellenoff, D., Karas, K., Moon, J., Neiss, S., Suber, R., \& Sorenson, O. (2016). The present and future of crowdfunding. Cal Mgmt Review, 58(2), 125-135.

[12] Bhattacharya, C.B., Korschun, D., \& Sen, S. (2009). Strengthening stakeholder-company relationships. Journal of Business Ethics, 85(2), 257272.

[13] Battilana, J., \& Dorado, S. (2010). Building sustainable hybrid organizations. Acad of Management Journal, 53(6), 1419-1440.

[14] Baty, G., \& Sommer, B. (2002). True then, true now. Venture Capital, 4(4), 289-293.

[15] Behr, P., Entzian, A., \& Güttler, A. (2011). How do lending relationships affect access to credit? J of Bank Fin, 35(8), 2169-78.

[16] Belleflamme, P., Lambert, T., \& Schwienbacher, A. (2014).

Crowdfunding: Tapping. J of Bus Vent, 29(5), 585-609.

[17] Berns, J.P., Figueroa-Armijos, M., da Motta Veiga, S.P., \& Dunne, T. (2020). Dynamics of lending-based prosocial crowdfunding. Journal of Business Ethics, 161(1), 169-185.

[18] Bollinger, B., \& Yao, S. (2018). Risk transfer versus cost reduction. Quant Marketing and Economics, 16(3), 251-287.
[19] Breedon, T. (2012). Boosting finance options for business. London, UK: Dep for Bus Innovation and Skills.

[20] Bruton, G., Khavul, S., Siegel, D., \& Wright, M. (2015). New financial alternatives. Ent Theory \& Practice, 39(1), 9-26.

[21] Burgess, R., \& Pande, R. (2005). Do rural banks matter? American Economic Review, 95(3), 780-795.

[22] Burke, K. (1984). Attitudes toward history. California: University of California Press.

[23] Burtch, G., Ghose, A., \& Wattal, S. (2014). Cultural differences and geography. MIS Quarterly, 38(3), 773-794.

[24] Calic, G., \& Mosakowski, E. (2016). Kicking off social entrepreneurship. J of Mgmt Studies, 53(5), 738-767.

[25] CGAP. (2004). Financial institutions with a double bottom line.

Washington, DC: Group to Assist the Poorest.

[26] Chowdhury, A. (2009). Crowdfunding as a poverty reduction tool. United Nations (Working Paper, 89).

[27] Colombo, M.G., Franzoni, C., \& Rossi-Lamastra, C. (2015). Internal social capital. Ent Theory and Practice, 39(1), 75-100.

[28] Cornelissen, J.P., \& Werner, M.D. (2014). Putting framing in perspective. Acad Mgmt Annals, 8(1), 181-235.

[29] Cheston, S., \& Kuhn, L. (2002). Empowering women through microfinance. UNIFEM.

[30] Crosetto, P., \& Regnier, T. (2014). Crowdfunding. Jena Economics Research Papers, 035.

[31] Crowdsourcing.org. (2014). 2014 economic value of crowdfunding. https://tinyurl.com/y2wm7h9f

[32] Dabson, B. (2001). Supporting rural entrepreneurship. Federal Reserve Bank of KC Proceedings, 27, 35-48.

[33] Davis, K., \& Blomstrom, R.L. (1966). Business and its environment. New York: McGraw-Hill.

[34] Davis, B.C., Hmieleski, K.M., Webb, J.W., \& Coombs, J.E. (2017). Funders' positive affective reactions to entrepreneurs. Journal of Bus Venturing, 32(1), 90-106.

[35] Defazio, D., Franzoni, C., \& Rossi-Lamastra, C. (2020). How pro-social framing affects. Journal of Business Ethics.

[36] Diaz-Garcia, C., Brush, C.G., Gatewood, E.J., \& Welter, F. (2016)

Women entrepreneurship in global and local contexts. Edward Elgar Publishing Inc.

[37] Dichter, T. (1999). Non-governmental organizations (NGOs) in crowdfunding. https://tinyurl.com/y $5 x$ gct9y

[38] Dichter, T.W., \& Harper, M. (Eds.). (2007). What's wrong with microfinance? Practical Action Pub.

[39] Dorfleitner, G., Priberny, C., Schuster, S., Stoiber, J., Weber, M., de Castro, I., \& Kammler, J. (2016). Description-text related soft information. Journal of Banking \& Finance, 64, 169-187.

[40] Dorfleitner, G., Oswald, E.M., \& Zhang, R. (2019). From credit risk to social impact. $J$ of Business Ethics.

[41] Drover, W., Wood, M.S., \& Fassin, Y. (2014). Take the money or run? J of Bus Venturing, 29(6), 723-740.

[42] Duarte, J., Siegel, S., \& Young, L. (2012). Trust and credit: The role of appearance in peer-to-peer lending. The Review of Financial Studies, 25(8), $2455-2484$

[43] Dushnitsky, G., \& Fitza, M.A. (2018). Are we missing the platforms for the crowd? J Bus Venturing Insights, 10.

[44] Epstein, M.J., \& Yuthas, K. (2010). Mission impossible. Sust Accounting, Mgmt and Policy J, 1, 201-221.

[45] Epstein, M.J., \& Yuthas, K. (2011). Protecting and regaining clarity of mission. Sust Accounting, Mgmt \& Pol J, 2(2), 322-330.

[46] Fassin, Y., \& Drover, W. (2017). Ethics in entrepreneurial finance. $J$ of Bus Ethics, 140(4), 649-672.

[47] Fehr, E., \& Schmidt, K. (2003). Theories of fairness and reciprocity. In M. Dewatripont, L.P. Hansen, \& S.J. Turnovsky (Eds.), Advances in Econ and Econometrics. Cambridge U Press.

[48] Figueroa-Armijos, M. (2019). Does Public Ent Fin Contribute to Territorial Servitization? Regional Studies, 53(3), 341-355.

[49] Figueroa-Armijos, M., Dabson, B., \& Johnson, T.G. (2012). Rural entrepreneurship in a time of recession. Ent Res $J, 2(1)$.

[50] Figueroa-Armijos, M., \& Johnson, T.G. (2013). Entrepreneurship in rural America. $J$ of Dev Ent, $18(2)$.

[51] Fiss, P.C., \& Hirsch, P.M. (2005). The discourse of globalization. American Sociological Review, 70(2), 29-52.

[52] Frey, B.S., \& Meier, S. (2004). Pro-Social Behavior in a Natural Setting. J of Econ Behavior \& Org, 54(1), 65-88.

[53] Friedman, M. (1970, Sept 13). The social responsibility of business. NYTimes, 32-33, 122, 126.

[54] Gaiha, R., \& Thapa, G. (2006). A methodology for assessment of the impact of microfinance on empowerment and vulnerability. Intl Fund for Agricultural Development.

[55] Galak, J., Small, D., \& Stephen, A.T. (2011). Crowdfunding decision making. J of Marketing Research, 48(SPL) 130-137. 
[56] Garriga, E.M., \& Mele, D. (2004). Corporate social responsibility theories. $J$ of Bus Ethics, 53(1-2), 51-71.

[57] Giorgi, S., \& Weber, K. (2015). Marks of distinction. Administrative Science Quarterly, 60(2), 333-367.

[58] Giudici, G., Guerini, M., \& Rossi-Lamastra, C. (2013). Why crowdfunding projects can succeed. SSRN 2255944

[59] Gladwin, C.H., Long, B.F., Babb, E.M., Beaulieu, L.J., Moseley, A., Mulkey, D., \& Zimet, D.J. (1989). Rural entrepreneurship. Am J of Ag Econ, 71(5), 1305-14.

[60] Goffman, E. (1974). Frame analysis. Harvard Univ Press.

[61] Greenberg, J., \& Mollick, E.R. (2014). Leaning in or leaning on? Academy of Management Proceedings.

[62] Hangl, C. (2014). A literature review about the landscape of social finance. Journal of Fin and Risk Perspectives, 3(4), 64-98.

[63] Heller, L.R., \& Badding, K.D. (2012). For compassion or money? The Journal of Socio-Econ, 41(6), 831-835.

[64] Hemingway, C.A., \& Maclagan, P.W. (2004). Managers' personal values as drivers of csr. J of Bus Ethics, 50(1), 33-44.

[65] Hermes, N., Lensink, R., \& Meesters, A. (2011). Outreach and efficiency of crowdfunding. World Dev, 39, 938-48.

[66] Hertog, J.K., \& McLeod, D.M. (2001). A multiperspectival approach to framing analysis. In S. D. Reese, O. H. Gandy, \& A. E. Grant (Eds.),

Framing public life (139-161). NY: Routledge.

[67] Herzenstein, M., Sonenshein, S., \& Dholakia, U.M. (2011). Tell me a good story. J of Marketing Research, 48(SPL), 138-149.

[68] Hildebrand, T., Puri, M., \& Rocholl, J. (2016). Adverse incentives. Mgmt Science, 63(3), 587-608.

[69] Hoetker, G. (2007). The use of logit and probit models in strategic mgmt research. Strat Mgmt J, 28(4), 331-343.

[70] Imai, K.S., Arun, T., \& Annim, S.K. (2010). Microfinance and

household poverty reduction. World Dev, 38(12), 1760-1774.

[71] Jenq, C., Pan, J., \& Theseira, W. (2015). Beauty, weight, and skin color in charitable giving. J of Econ Beh \& Org, 119, 234-53.

[72] Jin, Y., Rejesus, R.M., \& Little, B.B. (2005). Binary choice models. Applied Econ, 37(7), 841-848.

[73] Johnson, T.C. (2015). Reciprocity as a foundation of financial econ. Journal of Business Ethics, 131(1), 43-67.

[74] Joyner, B.E., Payne, D., \& Raiborn, C.A. (2002). Building values, business ethics and csr. Journal of Dev Ent, 7(1), 113-131.

[75] Kahle, L.R., Poulos, B., \& Sukhdial, A. (1988). Changes in social values in the US. Journal of Advertising Research, 35-41.

[76] Kabeer, N. (2001). Conflicts credit. World Dev, 29(1), 63-84.

[77] Kabeer, N. (2005). Is microfinance a 'magic bullet' for women's empowerment? Econ\&Pol Weekly, 40, 4709-18.

[78] Khandker, S.R. (2005). Microfinance and poverty. The World Bank Economic Review, 19(2), 263-286.

[79] Khavul, S. (2010). Microfinance. Acad Mgmt P, 24(3), 57-71. [80] Khavul, S., Bruton, G.D., \& Wood, E. (2009). Informal family business in Africa. Ent Theory and Practice, 33(6), 1219-1238.

[81] Khavul, S., Chavez, H., \& Bruton, G.D. (2013). When institutional change outruns the change. J Bus Vent, 28(1), 30-50.

[82] King, G., \& Zeng, L. (1999a). Logistic Regression in Rare Events Data. Harvard University. https://gking.harvard.edu/

[83] King, G., \& Zeng, L. (1999b). Estimating Absolute, Relative and Attributable Risks. https://gking.harvard.edu/

[84] Kiva. (2020a). \$1 billion in life-changing loans. Retrieved from: https://www.kiva.org/blog/1-billion-in-life-changing-loans

[85] Kiva. (2020b). About us -Statistics. Retrieved May 15, 2020 from: https://www.kiva.org/about

[86] Kiva. (2020c). Due diligence for field partner loans. Retrieved from: https://www.kiva.org/about/due-diligence/field-partner-role

[87] Kulviwat, S., Guo, C.Q., \& Engchanil, N. (2004). Determinants of online information search. Internet Research-Elec Networking Apps \&

Policy, 14(3), 245-253.

[88] Kuppuswamy, V., \& Bayus, B.L. (2017). Does my contribution matter? Journal of Business Venturing, 32(1), 72-89.

[89] Lanjouw, P., \& Shariff, A. (2004). Rural non-farm employment in India. Econ \& Pol Weekly, 39, 4429-4446.

[90] Ledgerwood, J., Earne, J., \& Nelson, C. (2013). The new microfinance handbook. Singapore: The World Bank.

[91] Li, Y., \& Zahra, S.A. (2012). Formal institutions, culture, and VC activity. $J$ of Bus Venturing, 27(1), 95-111.

[92] Lin, M., \& Viswanathan, S. (2015). Home bias in online investments. Mgmt Science, 62(5), 1393-1414.

[93] Low, S., Henderson, J., \& Weiler, S. (2005). Gauging a region's entrepreneurial potential. Economic Review.

[94] Ly, P., \& Mason, G. (2012). Competition between microfinance NGOs. World Development, 40(3), 643-655.

[95] Markley, D., Macke, D., \& Luther, V.B. (2005). Strategies for energizing entrepreneurs. Center for Lead Dev, 107-132.
[96] Marin, L., \& Ruiz, S. (2007). I need you too! Journal of Business Ethics, 71(3), 245-260.

[97] Marom, D., Robb, A., \& Sade, O. (2015). Gender dynamics in crowdfunding (Kickstarter). SSRN.

[98] Massolution. (2015). 2015CF Crowdfunding industry report. [99] McKenny, A.F., Allison, T.H., Ketchen, D.J., Short, J.C., \& Ireland, R.D. (2017). How should crowdfunding research evolve? Ent Theory and Practice, 41(2), 291-304

[100] McKnight, C., Dillon, A., \& Richardson, J. (1991). Hypertext in context (Vol. 6). Cambridge University Press.

[101] Minniti, M., \& Naude, W. (2010). What do we know about female ent across countries? Euro J of Dev Res, 22(3), 277-293.

[102] Mollick, E. (2014). The dynamics of crowdfunding. Journal of Business Venturing, 29(1), 1-16.

[103] Mollick, E., \& Nanda, R. (2015). Wisdom or madness? Management Science, 62(2), 1533-1553.

[104] Mollick, E., \& Robb, A. (2016). Democratizing innovation and capital. Cal Mgmt Review, 58(2), 72-87.

[105] Moss, T.W., Renko, M., Block, E., \& Meyskens, M. (2018). Funding the story of hybrid ventures. J of Bus Vent, 33(5), 643-59.

[106] Neumark, D., Wall, B., \& Zhang, J. (2011). Do small businesses create more jobs? R Econ \& Stats, 93(1), 16-29.

[107] Nilsson, J. (2008). Investment with a conscience. Journal of Business Ethics, 83(2), 307-325.

[108] O'Connor, M., \& Cuevas, J. (1982). The relationship of children's prosocial behavior. The J of Genetic Psy, 140(1), 33-45.

[109] Odell, K. (2010). Measuring the impact of crowdfunding. Grameen Foundation USA.

[110] Parhankangas, A., \& Renko, M. (2017). Linguistic style and crowdfunding success. Journal of Bus Venturing, 32(2), 215-236.

[111] Pope, D., \& Sydnor, J. (2011). What's in a picture? Journal of Human Resources, 46(1), 53-92.

[112] Posegga, O., Zylka, M.P., \& Fischbach, K. (2015). Collective dynamics of crowdfunding networks. HICSS

[113] Rhee, E.Y., \& Fiss, P.C. (2014). Framing controversial actions. Acad of Mgmt J, 57(6), 1734-1758.

[114] Robinson, M.S. (2001). The microfinance revolution. Washington, DC: The World Bank.

[115] Rodgers, W., Choy, H.L., \& Guiral, A. (2013). Do investors value a firm's commitment to social? J Bus Ethics, 114(4), 607-23.

[116] Rogaly, B. (1996). Micro-finance evangelism. Development in Practice, 6(2), 100-112.

[117] Secchi, D. (2009). The cognitive side of social responsibility. Journal of Business Ethics, 88(3), 565-581.

[118] Shahriar, A.Z.M., \& Garg, M. (2017). Lender-entrepreneur relationships and credit risk. Intl Small Bus J, 35(7), 829-854.

[119] Short, J.C., Ketchen, D.J., McKenny, A.F., Allison, T.H., \& Ireland, R.D. (2017). Research on crowdfunding. Ent Theory and Practice, 41(2), 149-160.

[120] Simanowitz, A. (2011). Challenges to the Field and Solutions. In Daley-Harris, S. \& Awimbo, A. (Eds.), New Pathways Out of Poverty, 53120. Kumarian Press.

[121] Swain, R.B., \& Floro, M. (2012). Assessing the effect of microfinance on vulnerability. J Dev Studies, 48(5), 605-618.

[122] Swain, R.B., \& Wallentin, F.Y. (2009). Does microfinance empower women? Intl Review of Applied Econ, 23(5), 541-556.

[123] Tchouassi, G. (2011). Microfinance, inequality, and vulnerability. Journal of Dev and Ag Econ, 3(3), 150-156.

[124] United Nations. (2006). Building inclusive financial sectors for development. Washington: UN Publications.

[125] Van Wingerden R., \& Ryan J. (2011). Fighting for funds. Lund University School of Econ and Mgmt, 65.

[126] Wennekers, S., \& Thurik, R. (1999). Linking ent and econ growth. Small Business Economics, 13(1), 27-55.

[127] Wilson, K.E., \& Testoni, M. (2014, September). Improving the role of equity crowdfunding. Bruegel policy 2014/09.

[128] Wooldridge, J.M. (2006). Introductory Econometrics: Thomson Learning: South-Western College.

[129] World Economic Forum. (2020). COVID response alliance for social ent. https://tinyurl.com/y6novouu

[130] Yu, S., Johnson, S., Lai, C., Cricelli, A., \& Fleming, L. (2017).

Crowdfunding. Research Policy, 46(10), 1723-1737.

[131] Yunus, M. (2007). Banker to the poor. New York.

[132] Zhang, H., \& Salvendy, G. (2001). The implications of visualization. Intl J of Human-Computer Interaction, 13(1), 75-95.

[133] Ziegler, T., Reedy, E., Le, A., Zhang, B., Kroszner, R.S., \& Garvey, K. (2017). The Americas alternative finance industry report 2017.

Cambridge Judge Bus School. 